\title{
The effect of foliar feeding on yield quality and the content of selected nutritive value components of three melon (Cucumis melo L.) cultivars
}

\author{
Anna Zaniewicz-Bajkowska, Jolanta Franczuk, \\ Edyta Kosterna, Robert Rosa, Marzena Panasz
}

\author{
Department of Vegetable Crops \\ University of Natural Sciences and Humanities in Siedlce \\ B. Prusa 14, 08-110 Siedlce, Poland \\ e-mail: warzywa@uph.edu.pl
}

\begin{abstract}
This study investigated the effect of foliar feeding with Florovit and Ekolist-Warzywa + urea liquid fertilisers on yield quality and the content of selected nutritive value components of three medium-fruit melon cultivars ('Charentais $\mathrm{F}_{1}$ ', 'Melba', and 'Fiesta'). A higher total yield was harvested from plants foliar-fed with Florovit and Ekolist-Warzywa + urea compared with the control without foliar feeding. The 'Fiesta' cultivar was characterised by the highest total yield. The type of foliar feeding significantly affected the total number of fruit per square metre. More fruit per metre squared was produced by Florovit-fed plants in comparison to EkolistWarzywa + urea. 'Charentais $\mathrm{F}_{1}$ ' produced the greatest number of fruit. 'Fiesta' had the highest proportion of marketable fruit. The factors investigated did not have any influence on the percentage of disease-affected and unripe fruit. The greatest amount of dry matter and ascorbic acid were determined in the fruit harvested from the control and plants foliar-fed with Ekolist-Warzywa + urea, respectively. The highest levels of both components were assayed in 'Fiesta'. Regardless of the type of foliar feeding, 'Fiesta' and 'Charentais $\mathrm{F}_{1}$ ' produced the highest quantity of total sugars and monosaccharaides as compared with 'Melba'.
\end{abstract}

Key words: biological value, Ekolist-Warzywa, Florovit, fruit quality, liquid fertilisers, yield

\section{INTRODUCTION}

Foliar feeding of plants is an important supplementation of soil fertilisation in vegetable cultivation. Foliar-fertilised plants deliver high yields of good quality at lower rates of mineral fertilisation (Nurzyński 1997, Osińska and Kołota 1998, Wójcik 1998, Biesiada et al. 2000, Kołota and Biesiada 2000, and Mareczek et al. 2000). Yildirim et al. (2007) claim that interest in foliar fertilisers has resulted from a rapid and effective response of foliar-fed plants, an opportunity to supply plants with nutrients regardless of soil conditions, and lower utilisation of mineral fertilisers.
Foliar fertilisation with nitrogen, phosphorus, potassium and microelements is recommended as the most effective method of eliminating nutrient deficiencies in vegetables (Trejo-Téllez et al. 2007).

The objective of the study was to determine the effect of foliar feeding with Florovit and a combination of Ekolist-Warzywa + urea on yield quality and content of selected nutritive value components of three medium-fruit melon cultivars.

\section{MATERIAL AND METHODS}

A field experiment was conducted in 2005-2007 at the experimental complex belonging to the University of Podlasie in Siedlce. The experiment 
Table 1. Characteristics of soil conditions before the start of the experiment

\begin{tabular}{lccccccccc}
\hline \multirow{2}{*}{ Year } & \multirow{2}{*}{$\mathrm{pH}$} & $\mathrm{C}-$-org $\%$ & ${\mathrm{~N}-\mathrm{NO}_{3}}$ & ${\mathrm{~N}-\mathrm{NH}_{4}}$ & $\mathrm{P}$ & $\mathrm{K}$ & $\mathrm{Ca}$ & $\mathrm{Mg}$ \\
\hline 2005 & 6.9 & 2.3 & 34.2 & 59.3 & 52.4 & 154.9 & 1950.3 & 66.0 \\
2006 & 7.2 & 2.0 & 21.9 & 48.6 & 43.8 & 197.0 & 2220.4 & 63.3 \\
2007 & 6.6 & 2.3 & 30.6 & 44.7 & 47.1 & 141.3 & 2089.0 & 66.0 \\
\hline Mean & 6.9 & 2.2 & 28.9 & 50.9 & 47.8 & 164.4 & 2086.6 & 65.1 \\
\hline
\end{tabular}

was set up as a randomised block design with four replications and was carried out on anthropogenic soil with Hortisol properties, which has been used as a part of horticultural farming for many years. It was a neutral reacting soil, characterised by a humus level of approximately $40 \mathrm{~cm}$ and average organic carbon content of $2.2 \%$ (Tab. 1). Before the experiment, the available phosphorus and potassium content was below the optimum limit whereas nitrogen, magnesium and calcium contents were slightly above this limit for field-grown cucumber (Sady 2000). These standards are also accepted for field-grown melon. Basic soil pre-plant fertilisation included Azofoska at a rate of $10 \mathrm{~kg}$ per $100 \mathrm{~m}^{2}$ of cultivated area.

The experiment investigated the effect of foliar feeding, double foliar application of Florovit $(0.25 \%)$, double foliar application of EkolistWarzywa $(0.5 \%)+$ urea $(0.1 \%)$ on yield quality and content of selected nutritive value components of three melon cultivars with medium-sized fruit: 'Charentais $\mathrm{F}_{1}$ ', 'Melba', and 'Fiesta'. EkolistWarzywa liquid fertiliser contains (\% weight): $\mathrm{N}$ 4, $\mathrm{MgO}-5, \mathrm{~S}-4.3, \mathrm{~B}-0.56, \mathrm{Cu}-0.60, \mathrm{Fe}-0.67$, $\mathrm{Mn}-1$, Mo - 0.004, and $\mathrm{Zn}-0.60$, while Florovit contains: $\mathrm{N}-3 \%, \mathrm{~K}_{2} \mathrm{O}-2 \%$ and $\left(\mathrm{mg} \mathrm{dm}^{-3}\right) \mathrm{Cu}-70$, $\mathrm{Fe}-400, \mathrm{Mn}-170$, Mo - 20, and $\mathrm{Zn}-150$. The control treatments were a combination without foliar feeding.

Melon seedlings were grown in a non-heated greenhouse. Before the planting of seedlings in the field, they were hardened off and vine tops were removed so that each plant had three leaves. The seedlings were moved permanently outdoors and planted in the $1^{\text {st }} 10$ days of June and covered with agrotextile, which was removed at the beginning of flowering. Melon seedlings were planted at an 80 $\mathrm{cm} \times 100 \mathrm{~cm}$ spacing, 10 plants per plot. The plot area for harvest was $8 \mathrm{~m}^{2}$.

When fruit buds were of walnut size, excessive buds were removed, leaving the largest eight on the plant. Moreover, the fruit-bearing vines were shortened, leaving two leaves located close to the bud. Additionally, vines not bearing fruit were removed.

At the beginning of flowering and following cutting, solutions of liquid foliar feeds Florovit and Ekolist-Warzywa + urea were applied, which represent multi-nutrient fertilisers, in the quantity $0.03 \mathrm{dm}^{3}$ liquid per $1 \mathrm{~m}^{2}$.

Fruit harvest was performed once a week as fruit ripened (from the $3^{\text {rd }}$ third of August to the $1^{\text {st }}$ third of September). During the harvest we determined the total yield $\left(\mathrm{kg} \mathrm{m}^{-2}\right)$, total fruit number (plant per $\mathrm{m}^{-2}$ ) and the percentage share of marketable, unripe and disease-affected fruit (showing symptoms of decay) within the total fruit number. The marketable fruit harvested in the third term of harvest (end of $1^{\text {st }}$ third of September) were sampled for a chemical analysis in order to determine the following contents: dry matter - using the ovendrying gravimetric method (PN-90/A-75101/03), total sugars and monosaccharaides - with the Luff Schoorl method (PN-90/A-75101/07), and ascorbic acid - according to the Pijanowski method (Gronowska-Senger 1987).

The results of the experiment were statistically analysed by means of the analysis of variance. The significance of differences was verified using the Tukey test at $\mathrm{p}=0.05$.

The weather conditions varied during the years of the study. The least favourable for melon growth and performance was the year 2006, which was characterised by a relatively high mean air temperature, accompanied by considerably irregular precipitation patterns. In the years 2005 and 2007, weather conditions were more favourable for melon.

\section{RESULTS AND DISCUSSION}

Weather conditions in the consecutive years of the study had a significant influence on the level of total yield of melon fruit (Tab. 2). The significantly highest total yield $\left(3.30 \mathrm{~kg} \mathrm{~m}^{-2}\right)$ was obtained in 2007, when weather conditions favoured melon cultivation. On the basis of the results of this study, 
Table 2. Total yield of melon fruit $\left(\mathrm{kg} \mathrm{m}^{-2}\right)$ in the consecutive years of the study

\begin{tabular}{|c|c|c|c|c|c|}
\hline \multirow{2}{*}{ Year } & \multirow{2}{*}{$\begin{array}{l}\text { Type of foliar } \\
\text { feeding }\end{array}$} & \multicolumn{3}{|c|}{ Cultivar } & \multirow{2}{*}{ Mean } \\
\hline & & 'Charentais $\mathrm{F}_{1}$ ' & 'Melba' & 'Fiesta' & \\
\hline \multirow{3}{*}{2005} & I & 2.54 & 1.45 & 2.29 & 2.09 \\
\hline & II & 2.72 & 1.45 & 3.02 & 2.40 \\
\hline & III & 2.66 & 1.59 & 2.82 & 2.36 \\
\hline \multirow[t]{2}{*}{ Mean } & & 2.64 & 1.50 & 2.71 & 2.28 \\
\hline & I & 2.54 & 2.02 & 2.91 & 2.49 \\
\hline \multirow[t]{2}{*}{2006} & II & 2.86 & 2.07 & 2.51 & 2.48 \\
\hline & III & 3.04 & 2.14 & 3.06 & 2.75 \\
\hline \multirow[t]{2}{*}{ Mean } & & 2.81 & 2.08 & 2.83 & 2.57 \\
\hline & I & 2.32 & 2.27 & 3.27 & 2.62 \\
\hline \multirow[t]{2}{*}{2007} & II & 2.38 & 2.70 & 5.06 & 3.38 \\
\hline & III & 2.90 & 2.21 & 6.62 & 3.91 \\
\hline \multirow[t]{2}{*}{ Mean } & & 2.53 & 2.39 & 4.98 & 3.30 \\
\hline & I & 2.47 & 1.91 & 2.82 & 2.40 \\
\hline \multirow[t]{2}{*}{ Mean } & II & 2.65 & 2.07 & 3.53 & 2.75 \\
\hline & III & 2.87 & 1.98 & 4.17 & 3.01 \\
\hline Mean for cultivar & & 2.66 & 1.99 & 3.51 & 2.72 \\
\hline
\end{tabular}

*I - control; II - Florovit; III - Ekolist-Warzywa + urea

we found a significant interaction between foliar feeding type $\times$ cultivar on total yield of melon fruit. In the control (without foliar feeding), the highest total yield was produced by 'Fiesta' $\left(2.82 \mathrm{~kg} \mathrm{~m}^{-2}\right)$, with 'Charentais $\mathrm{F}_{1}$ ' delivering a similar yield (2.47 $\mathrm{kg} \mathrm{m}^{-2}$ ). Compared with the above cultivars, a significantly lower yield was found in 'Melba'. The difference ranged from $0.91 \mathrm{~kg} \mathrm{~m}^{-2}$ for 'Fiesta' and $0.56 \mathrm{~kg} \mathrm{~m}^{-2}$ for 'Charentais $\mathrm{F}_{1}$ '. In the treatments foliar-fed with Florovit and Ekolist-Warzywa + urea, the highest total yield was recorded for 'Fiesta': 3.53 and $4.17 \mathrm{~kg} \mathrm{~m}^{-2}$, respectively. In the Florovit-fed treatments, the differences amounted to 0.88 and $1.46 \mathrm{~kg} \mathrm{~m}^{-2}$, as compared with 'Charentais $F_{1}$ ' and 'Melba', respectively. In the treatments where plants were foliar-fed with Ekolist-Warzywa + urea, the differences equalled 1.30 and $2.19 \mathrm{~kg} \mathrm{~m}^{-2}$, respectively. The total yield of 'Charentais $\mathrm{F}_{1}$ ' was significantly higher compared with 'Melba'. Yildirim et al. (2007) reported a significant influence of foliar feeding with urea on the yield and quality of broccoli. Soil fertilisation with nitrogen and supplemental foliar feeding with urea increased broccoli head weight and diameter as well as the weight and height of the plants. Similarly, additional foliar feeding with urea resulted in an increased broccoli yield in the study by Rożek and Wojciechowska (2005). Also, Sady et al. (2005) found that foliar feeding with
Supervit-R and urea had a favourable influence on carrot root yield. Kołota and Osińska (2001) reported a significant increase in cabbage yield as a result of the application of foliar feeding with multi-nutrient fertilisers containing nitrogen. Dzida and Jarosz (2005) reported a higher yield of tomato after foliar feeding with potassium, magnesium and calcium Plonochron.

The cultivars examined differed significantly in terms of the total number of fruit per metre squared (Fig. 1). 'Charentais $F_{1}$ ' and 'Fiesta' produced significantly more fruit than 'Melba'. The differences amounted to 1.95 and 1.78 fruits per $\mathrm{m}^{2}$, respectively. The type of foliar feeding had a significant influence on the total number of fruit per metre squared. The total number of fruit per square metre of Florovit-fertilised plants amounted to 5.22 fruits per $\mathrm{m}^{2}$ and was higher by 0.41 fruits per $\mathrm{m}^{2}$ than in the control without foliar feeding. The difference was statistically significant. The application of Ekolist-Warzywa + urea was followed by an insignificant increase in total fruit number compared with the control.

The highest proportion of marketable fruit in total fruit number was associated with 'Fiesta' (55.66\%), was slightly lower in 'Charentais $\mathrm{F}_{1}$ ' $(51.00 \%)$, and significantly lower (by 9.38\%) in 'Melba' (Tab. 3). Biesiada and Kołota (2001) showed that foliar feeding with Ekolist PK and Ekolist S significantly 


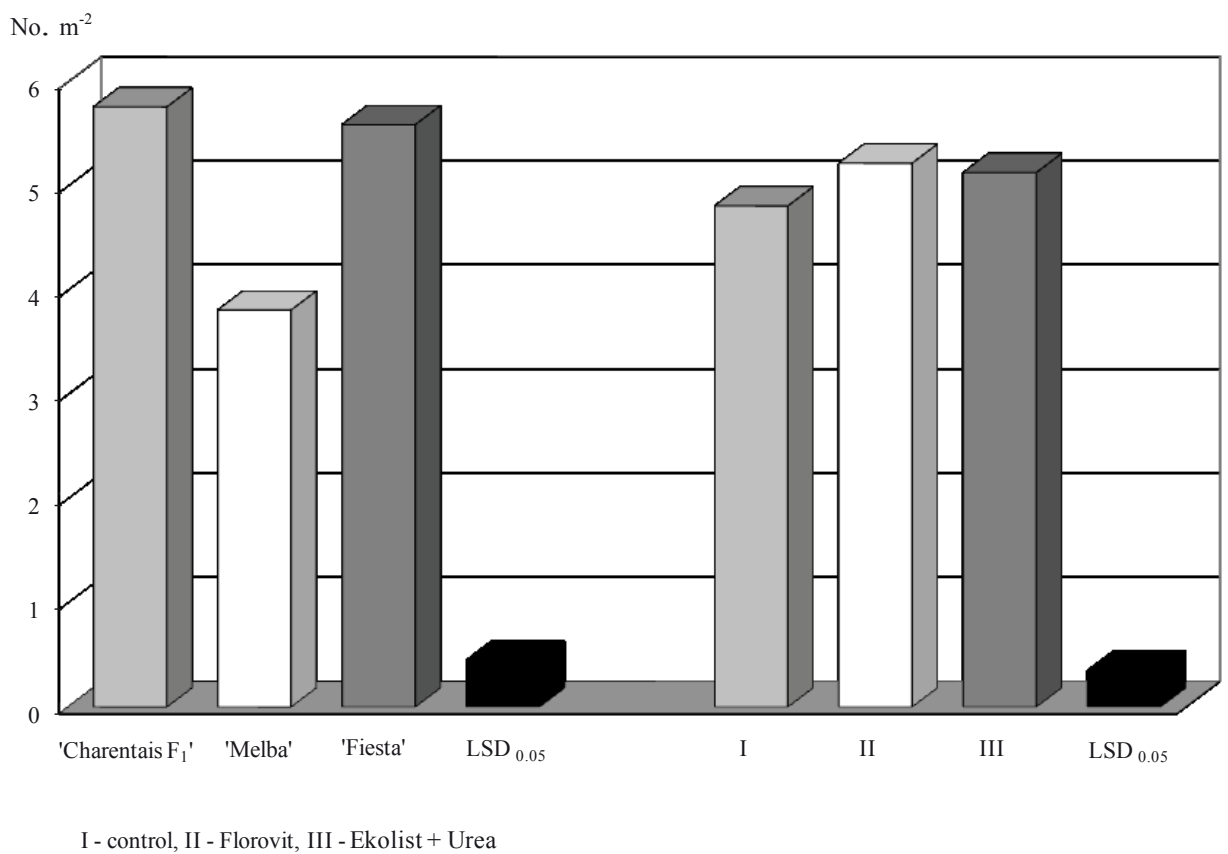

Figure 1. Total number of fruit per metre squared - mean for the years 2005-2007

increased cabbage marketable yields. The increase in marketable yield as a result of foliar feeding ranged from 5.2 to $9.4 \%$ as compared to the plots with soil fertilisation. Kołota and Osińska (2001) applied foliar feeding with Ekolist, which resulted in an increase in the marketable yield of cabbage (by $20.3 \%$ ), cucumber $(7.3 \%$ ) and onion $(10.8 \%)$.

No significant impact of the factors investigated in this study was found on the percentage of disease- affected and unripe fruit in the total number of fruit per metre squared (Tab. 3).

The results of this study revealed a significant interaction between the type of foliar feeding and cultivar on dry matter and ascorbic acid content in melon fruit (Tab. 4).

In the control and Florovit-fed treatments, the dry matter content of 'Fiesta' and 'Charentais $\mathrm{F}_{1}$ ' fruit did not differ significantly. In the treatments

Table 3. The percentage share of marketable, disease-affected and unripe fruit in the total number of fruit per metre squared - mean for the years 2005-2007

\begin{tabular}{|c|c|c|c|c|c|}
\hline \multirow{2}{*}{ Share of fruit } & \multirow{2}{*}{$\begin{array}{l}\text { Type of foliar } \\
\text { feeding }\end{array}$} & \multicolumn{3}{|c|}{ Cultivar } & \multirow{2}{*}{ Mean } \\
\hline & & 'Charentais $\mathrm{F}_{1}$ ' & 'Melba' & 'Fiesta' & \\
\hline \multirow{3}{*}{ Marketable fruit } & I & 49.91 & 45.97 & 53.17 & 49.68 \\
\hline & II & 50.66 & 46.48 & 56.33 & 51.16 \\
\hline & III & 52.42 & 46.38 & 57.47 & 52.09 \\
\hline Mean & & 51.00 & 46.28 & 55.66 & 50.99 \\
\hline \multicolumn{6}{|c|}{$\mathrm{LSD}_{0.05}$ for: type of foliar feeding $=$ n.s.; cultivar $=5.02 ;$ type of foliar feeding $\times$ cultivar $=$ n.s. } \\
\hline \multirow{3}{*}{ Disease-affected fruit } & $\mathrm{I}$ & 14.83 & 21.06 & 17.64 & 17.84 \\
\hline & II & 16.76 & 22.51 & 17.01 & 18.76 \\
\hline & III & 14.93 & 18.48 & 15.27 & 16.22 \\
\hline Mean & & 15.51 & 20.68 & 16.64 & 17.61 \\
\hline \multicolumn{6}{|c|}{$\mathrm{LSD}_{0.05}$ for: type of foliar feeding = n.s.; cultivar $=$ n.s.; type of foliar feeding $\times$ cultivar $=$ n.s. } \\
\hline \multirow{3}{*}{ Unripe fruit } & $\mathrm{I}$ & 35.25 & 32.97 & 29.19 & 32.47 \\
\hline & II & 32.58 & 31.01 & 26.65 & 30.08 \\
\hline & III & 32.65 & 35.14 & 27.26 & 31.68 \\
\hline Mean & & 33.50 & 33.04 & 27.70 & 31.41 \\
\hline
\end{tabular}

$\mathrm{LSD}_{0.05}$ for: type of foliar feeding $=$ n.s.; cultivar $=$ n.s.; type of foliar feeding $\times$ cultivar $=$ n.s.

*I - control; II - Florovit; III - Ekolist-Warzywa + urea 
Table 4. Nutritious component content in melon fruit - mean for the years 2005-2007

\begin{tabular}{|c|c|c|c|c|c|}
\hline \multirow{2}{*}{ Nutritious components } & \multirow{2}{*}{$\begin{array}{l}\text { Type of foliar } \\
\text { feeding }\end{array}$} & \multicolumn{3}{|c|}{ Cultivar } & \multirow{2}{*}{ Mean } \\
\hline & & 'Charentais $\mathrm{F}_{1}$ ' & 'Melba' & 'Fiesta' & \\
\hline \multirow{3}{*}{ Dry matter (\%) } & I & 5.63 & 4.66 & 5.71 & 5.33 \\
\hline & II & 5.45 & 4.62 & 5.56 & 5.21 \\
\hline & III & 5.44 & 4.56 & 5.77 & 5.26 \\
\hline Mean & & 5.51 & 4.61 & 5.68 & 5.27 \\
\hline \multicolumn{6}{|c|}{$\mathrm{LSD}_{0.05}$ for: type of foliar feeding $=$ n.s.; cultivar $=0.22 ;$ type of foliar feeding $\times$ cultivar $=0.17$} \\
\hline \multirow{3}{*}{$\begin{array}{l}\text { Total sugars } \\
\text { (\% f.m.) }\end{array}$} & I & 4.46 & 3.63 & 4.64 & 4.24 \\
\hline & II & 4.46 & 3.55 & 4.48 & 4.16 \\
\hline & III & 4.33 & 3.37 & 4.49 & 4.06 \\
\hline \multicolumn{2}{|l|}{ Mean } & 4.42 & 3.52 & 4.54 & 4.16 \\
\hline \multicolumn{6}{|c|}{$\mathrm{LSD}_{0.05}$ for: type of foliar feeding $=0.11 ;$ cultivar $=0.23 ;$ type of foliar feeding $\times$ cultivar $=$ n.s. } \\
\hline \multirow{3}{*}{$\begin{array}{l}\text { Monosaccharaides ( } \% \\
\text { f.m.) }\end{array}$} & I & 1.13 & 0.88 & 1.13 & 1.04 \\
\hline & II & 1.07 & 0.92 & 1.08 & 1.02 \\
\hline & III & 1.10 & 0.89 & 1.09 & 1.03 \\
\hline \multicolumn{2}{|l|}{ Mean } & 1.10 & 0.90 & 1.10 & 1.03 \\
\hline \multicolumn{6}{|c|}{$\mathrm{LSD}_{0.05}$ for: type of foliar feeding $=$ n.s.; cultivar $=0.05 ;$ type of foliar feeding $\times$ cultivar $=$ n.s. } \\
\hline \multirow{3}{*}{$\begin{array}{l}\text { Ascorbic acid } \\
(\mathrm{mg} \%)\end{array}$} & I & 17.19 & 17.07 & 18.19 & 17.48 \\
\hline & II & 16.60 & 18.45 & 17.63 & 17.56 \\
\hline & III & 18.09 & 17.52 & 18.00 & 17.87 \\
\hline \multicolumn{2}{|l|}{ Mean } & 17.29 & 17.68 & 17.94 & 17.64 \\
\hline \multicolumn{6}{|c|}{$\mathrm{LSD}_{0.05}$ for: type of foliar feeding $=$ n.s.; cultivar $=$ n.s.; type of foliar feeding $\times$ cultivar $=0.93$} \\
\hline
\end{tabular}

foliar-fed with Ekolist-Warzywa + urea, 'Fiesta' had a higher dry matter content as compared with 'Charentais $\mathrm{F}_{1}$ '. Of all of the combinations, 'Melba' fruit had the significantly lowest dry matter content.

In the control, the significantly highest ascorbic acid content was recorded for 'Fiesta' fruit. In the treatments where plants were foliar-fed with Florovit, 'Fiesta' and 'Melba' fruit had significantly more ascorbic acid than 'Charentais $\mathrm{F}_{1}$ '.

Melon fruit contents of total sugars and monosaccharaides depended on the cultivar (Tab. 4). Significantly higher total sugars and monosaccharaide contents were determined in the fruit of 'Charentais $\mathrm{F}_{1}$ ' and 'Fiesta' in comparison to 'Melba'.

In studies by several other researchers, foliar feeding did not affect the biological value of vegetables (Kołota and Biesiada 2000, Mareczek et al. 2000, Kowalska et al. 2006, Smoleń et al. 2006) nor decrease the nutrient content in vegetables (Biesiada et al. 2000, Yildirim et al. 2007). In studies by Dzida and Jarosz (2005), foliar feeding with Plonochron combined with varied nitrogen fertilisation increased total sugar content. However, it did not have any influence on vitamin $\mathrm{C}$ content in tomato.

\section{CONCLUSIONS}

1. The significantly highest total yield was achieved in 2007 with relatively high air temperature and low rainfall towards the end of the melon growing period.

2. A higher total yield of melon fruits was harvested from plants foliar-fed with Florovit and EkolistWarzywa + urea as compared with the control without foliar feeding. Amongst the tested cultivars, 'Fiesta' had the highest total yield.

3. More fruit per metre squared was produced by Florovit-fed plants in comparison with EkolistWarzywa + urea. 'Charentais $\mathrm{F}_{1}$ ' produced the greatest fruit number. 'Fiesta' had the highest proportion of marketable fruit yield as compared with the total .

4. The factors investigated did not influence the percentage of disease-affected and unripe fruit.

5. Higher quantities of dry matter and ascorbic acid were determined in the fruit harvested from the control and plants foliar-fed with EkolistWarzywa + urea. The highest levels of both components were found in the 'Fiesta' cultivar. 
6. Regardless of the type of foliar feeding, 'Fiesta' and 'Charentais $F_{1}$ ' produced the highest contents of total sugars and monosaccharaides.

\section{REFERENCES}

Biesiada A., KоєотA E., 2001. Wpływ nawożenia dolistnego na plonowanie kapusty głowiastej białej. Ogólnopol. Konf. Nauk. „Biologiczne i agrotechniczne kierunki rozwoju warzywnictwa", 21-22 czerwiec, Skierniewice: 86-88.

Biesiada A., Kolota E., Osińska M., Michalak K., 2000. Wpływ nawożenia dolistnego na wybrane wskaźniki wartości odżywczej warzyw. Zesz. Nauk. AR w Krakowie 364: 53-56.

Dzida K., Jarosz Z., 2005. Effect of different levels of nitrogen fertilization and additional foliage feeding on the yield and some elements in leaves and fruits of tomato. Ann. Univ. M. Curie-Skłodowska, Sect. EEE, XV: 51-58.

Gronowska-Senger A., 1987. Ćwiczenia z analizy żywności. Wyd. SGGW - AR Warszawa: 90.

KoŁota E., Biesiada A., 2000. The effect of foliar fertilization on yield and quality of carrot roots. Roczn. AR Poznań CCCXXIII, Ogrodnictwo 31(1): 331-335.

KoŁota E., OsińsKa M., 2001. Efficiency of foliar nutrition of field vegetables grown at different nitrogen rates. Acta Hort. 563: 87-91.

Kowalska I., SAdy W., SzUra A., 2006. Effects of nitrogen form, foliar nutrition and growing place on yield and quality of lettuce. Acta Agroph. 7(3): 619-631.

Mareczek A., Rożek S., SAdy W., 2000. Wpływ pozakorzeniowego dokarmiania roślin na wielkość i jakość plonu dyni. Zesz. Nauk. AR w Krakowie 364: 131-134.

NURZYŃSKI J., 1997. Pozakorzeniowe stosowanie nawozów mineralnych. VI Konf. Katedr Uprawy Roli i Nawożenia Roślin Ogrodniczych, 20-21 czerwiec, Kraków: 27-31.

OsińSKA M., КоєотA E., 1998. Utilization of Ekolist in foliar nutrition of field vegetable crop grown at different nitrogen rates. Folia Univ. Agric. Stetin., Agricult. 190(72): 247-252.

PN-90 A-75101/03. Oznaczanie zawartości suchej masy metodą wagową.

PN-90/A-75101/07. Oznaczanie zawartości cukrów i ekstraktu bezcukrowego.

RożEK S., Wojciechowska R., 2005. Effect of foliar urea application and different levels of nitrogen in soil on yield and its quality of broccoli heads in autumn growing cycle. Hort. Veg. Growing 24(3): 291-301.

SADY W., 2000. Nawożenie warzyw polowych. Plantpress, Kraków.

SAdy W., Smoleń S., RożeK S., 2005. Effect of differentiated nitrogen fertilization and foliar application on yield and biological quality of carrot crop. Hort. Veg. Growing 24(3): 273-281.
Smoleń S., Wojciechowska R., Sady W., Szura A., 2006. Effect of fertilization with different forms of nitrogen and foliar nutrition on yield and nitrogen metabolism in carrot roots (Daucus carota L.). Acta Agroph. 7(3): 721-732.

Trejo-Téllez L.I., Rodriguez-Mendoza M.N., AlcÁntar -GonzÁlez G., Gómez-Merino F.C., 2007. Effect of foliar fertilization on plant growth and quality of Mexican Husk Tomato (Physalis Ixocarpa Brot.). Acta Hort. 729: 295-299.

Wóıcıк P., 1998. Pobieranie składników mineralnych przez części nadziemne roślin $\mathrm{z}$ nawożenia pozakorzeniowego. Post. Nauk Roln. 1: 49-64.

Yildirim E., Guvenc I., Turan M., Karatas A., 2007. Effect of foliar urea application on quality, growth, mineral uptake and yield of broccoli (Brassica oleracea L., var. italica). Plant Soil Environ., 53(3): 120-128.

\section{WPEYW DOKARMIANIA DOLISTNEGO NA JAKOŚĆ PLONU I WYBRANE ELEMENTY WARTOŚCI ODŻYWCZEJ TRZECH ODMIAN MELONA (CUCUMIS MELO L.)}

Streszczenie: Badano wpływ dokarmiania dolistnego nawozami płynnymi: Florovit i EkolistWarzywa z dodatkiem mocznika na jakość plonu i wybrane elementy wartości odżywczej trzech średnioowocowych odmian melona ('Charentais $\mathrm{F}_{1}$,, 'Melba', 'Fiesta'). Większy plon ogólny zebrano $\mathrm{z}$ roślin dokarmianych dolistnie Florovitem i Ekolistem-Warzywa $\mathrm{z}$ dodatkiem mocznika $\mathrm{W}$ porównaniu $\mathrm{z}$ kontrolą (bez dokarmiania dolistnego). Największym plonem ogólnym charakteryzowała się odmiana 'Fiesta'. Rodzaj dokarmiania dolistnego miał istotny wpływ na łączną liczbę owoców z $1 \mathrm{~m}^{2}$. Więcej owoców z $1 \mathrm{~m}^{2}$ zebrano z roślin dokarmianych Florovitem niż Ekolistem-Warzywa z mocznikem. Najwięcej owoców uzyskano $\mathrm{z}$ odmiany 'Charentais $\mathrm{F}_{1}$ '. Największym procentowym udziałem owoców handlowych charakteryzowała się odmiana 'Fiesta'. Nie stwierdzono istotnego wpływu badanych czynników na procentowy udział owoców porażonych przez choroby oraz niedojrzałych. Najwięcej suchej masy zawierały owoce zebrane $\mathrm{z}$ obiektu kontrolnego, a kwasu askorbinowego rośliny dokarmiane EkolistemWarzywa z mocznikiem. Owoce odmiany 'Fiesta' charakteryzowały się największą zawartością tych składników. Niezależnie od rodzaju dokarmiania dolistnego najwięcej cukrów ogółem i redukujących miały owoce odmian 'Fiesta' $\mathrm{i}$ 'Charentais $\mathrm{F}_{1}$ ' w porównaniu z odmianą 'Melba'.

Received February 8, 2010; accepted September 15, 2011 